\title{
Climate-smart soil water and nutrient management options in semiarid West Africa: a review of evidence and analysis of stone bunds and zaï techniques
}

\author{
Robert Zougmoré ${ }^{*}$, Abdulai Jalloh ${ }^{2}$ and Andre Tioro ${ }^{3}$
}

\begin{abstract}
There is an increasing need for West African Sahel farmers to be availed with appropriate technologies and management practices that sustainably increase productivity and resilience, while reducing greenhouse gas emissions where possible. In this paper, we analysed prevailing key water and nutrient interaction practices namely stone bund, zaï and half-moon techniques in order to explore how their outcomes could be linked to climate change adaptation and mitigation. Data were derived from previous publications but were reinterpreted in the angle of technologies' alignment with the three pillars of climate-smart agriculture (CSA). We found that the most successful systems are those that provide water, nutrients and a supportive soil structure in a synergistic manner. Indeed, technologies such as zaï, half-moons and stone bunds, combined with an application of organic/inorganic sources of nutrients, are promising climate-smart agricultural practices that could be widely used by smallholder farmers to maintain food production and secure farmers' livelihoods, while contributing to ecosystem services. However, accompanying incentive measures are needed to empower and capacitate rural farmers to adopt the considered techniques. These are successful examples that can form the basis for informing farmers and agricultural extensionists, as well as future agricultural development plans, policies and investments that pursue sustainable food and nutritional security in the West African Sahel.
\end{abstract}

Keywords: Climate change, Climate-smart agriculture, Soil and water management, Food security, Sahel

\section{Introduction}

The population of West Africa has quadrupled over 50 years (from 90 million in 1960 to 342 million in 2011) [1]. This rapid population growth has had a huge impact on the food demand. Many smallholder farmers must deal with low and unpredictable crop yields and incomes, as well as chronic food insecurity. These challenges are particularly acute in the dry lands, where land degradation, depleted soil fertility, water stress and high costs of fertilizers contribute to low crop yields [2]. Nearly $3.3 \%$ of agricultural GDP in sub-Saharan Africa is lost annually because of soil and nutrient losses, estimated at over $30 \mathrm{~kg} / \mathrm{ha} /$ year [3].

\footnotetext{
* Correspondence: r.zougmore@cgiar.org

${ }^{1}$ CGIAR Research Program on Climate Change, Agriculture and Food Security (CCAFS), ICRISAT Bamako, BP 320 Bamako, Mali

Full list of author information is available at the end of the article
}

Climate change brings additional threats arising from stresses and shocks caused by higher temperatures and a lack of rainfall. According to Lobell et al. [4], the potential yield loss due to the climate change impact is about $5 \%$ for each degree Celsius of global warming.

The Sahel region in West Africa covers approximately 5.7 million $\mathrm{km}^{2}$ and is home to about 58 million people. Due to its geographic location at the southern edge of the Sahara desert, the region is highly vulnerable to climate change as its population livelihood depends on rain-fed agriculture and livestock. Over the years, crop-livestock production systems in the Sahel have been adapting their practices and ways of life to various risks: climatic variability, economic risks and livestock diseases. To cope with shocks and crisis but also to support changes, various strategies based on the mobility of livestock and/or families, reorganization and diversification of activities, reciprocity 
and social networks have been developed and used successfully. Integrating climate change adaptation and mitigation may ensure food security and also reduce agriculture ecological footprint. Adaptation is a priority for smallholder farmers, who will pursue mitigation when it brings benefits without increasing costs and risks [5].

Climate-smart agriculture (CSA) is an approach that can greatly help us achieve this target. In a recent article, Neufeldt et al. [6] provided substantial information on the concept and its implications. It embraces multiple objectives, aims to increase agricultural productivity and farmers' income, strengthens the resilience of ecosystems and livelihoods to climate change and reduces greenhouse gas emissions. As there are huge variations between geographic locations in terms of risks to be faced and capacities to face them, CSA takes into consideration context-specific and locally adapted actions and interventions, along the whole agricultural value chain.

In semiarid West Africa, where major constraints that impinge on agricultural development are droughts, soil acidity and nutrient depleted and degraded soils [7], most successful CSA options will require a synergistic provision of water, nutrients and a supportive soil structure. These are the key elements needed to support effective plant growth and to reduce crop failure. Water and nutrient interaction practices such as zaï and halfmoons techniques, fertilizer micro-dosing, stone bunds or vegetation strips combined with an application of organic/inorganic sources of nutrients, cereal-legume intercropping, crop-livestock systems appear to be promising CSA options in the Sahel. Indeed, constructing stone bunds along the contours is an effective way to harvest rain water and decrease run-off erosion in the field [8]. Stone bunding was primarily an indigenous practice that has been later on improved through action research on various parameters (slope, spacing, number of stone lines per bund, etc.) [9]. Also initiated by farmers in West Africa, the zai and half-moon are indigenous practices that consist in concentrating run-off water and organic matter in small pits (zai) or semicircular basins (half-moons). Stone bunds, zä̈ and halfmoons are improved land management techniques that often lead to improved soil fertility and soil moisture. Applied at a watershed scale, they also increase ground water level and tree cover [10]. This paper analysed the ability of the above existing technologies and practices and explore how their outcomes are linked to climate change adaptation and mitigation and to increased agricultural resilience in West Africa. This may help in clarifying the concept of CSA through concrete examples while paving appropriate approaches to promote CSA amongst a wide variety of stakeholders in agricultural development.

\section{Climate change projections for semiarid West Africa}

Recorded variability in the climate of West Africa during the last century concluded that 1930-1960 was a wet period and 1970-1980 was a drought slot and the good rainfall seasons returned in the 1990s and 2000s [11]. The 1980s have been declared the driest years in the twentieth century, though an increasing trend in precipitation has been observed over the past 15 years [11]. The complex nature of West Africa's climate, dominated by the monsoon, makes it challenging for reanalysis and GCMs to accurately capture the temporal and spatial variability observed in the region [12]. In recent decades, decreased precipitation and drought in the Sahel has become a particular focus for research as it represents one of the largest recent observed climate changes of any region [13]. According to Washington and Hawcroft [14], the projections for changes in crop cultivation limits are variable over space and time, and so the outlook for agriculture is highly uncertain, particularly in the vulnerable Sahelian region. Insufficient observational records constrain the accuracy of reanalysis and gridded data, making the identification of local trends and mechanisms difficult. In addition, there is wide divergence in model projections for the region's climate by the end of this century. This poses a significant challenge to designing agricultural adaptation strategies.

Two physically consistent scenarios for the Sahel have been put forward; one drying and one wetting [15]. Simplistically, the drying interpretation centers on overall warming of the oceans and associated oceanic convection, leading to decreased convection at the continental margins and resultant drying of the interior. Alternatively, a wetter Sahel could be caused by an enhanced land-sea temperature gradient, either due to greater warming of the land and a stronger monsoon flow or due to a reversal in the north-south Atlantic sea surface temperature gradient [16]. Washington and Hawcroft [14] concluded that the evidence therefore remains inconclusive as to whether a climatological increase or decrease in precipitation is the more plausible projection of change for the Sahel. A study by Ericksen et al. [17] indicated that the length of growing period will decline by $5 \%$ or more across a broad area of the global tropics, including heavily cropped areas of West Africa. The IPCC [18] predicts an approximate $50 \%$ decrease in yields from rain-fed agriculture by 2020 in some countries. The recent study by Jalloh et al. [7], covering 11 West African countries, reported detailed projection results for major crops such as millet, sorghum, maize, rice, groundnut, beans, cassava, cocoyam and cotton. The models predict significant decline in crop yields between 2000 and 2050 if no adaptation measures are undertaken. As an example, CSIRO and MIROC models predict a general decrease in maize yields of $5 \%-25 \%$ over a baseline in most parts 
of countries which lie on the southern coast of West Africa and a yield increase of 5\%-25\% in the Sahel zone [7].

Also, heavy and persistent rainfall in hitherto dry areas of the Sahel could cause an increase in diseases and pests to which livestock in those areas are not adapted. On the other hand, a marked decrease in rainfall in hitherto wet regions like Liberia could cause significant changes in the growing conditions that may require changes in the farming system with regard to crops and livestock composition and management [7]. The real issue is the inability of resource-poor farmers to react appropriately and fast enough. Unless strong adaptation measures are taken, projected changes in rainfall and temperatures may cause significant declines in crop yields in semi-arid, tropical and sub-tropical regions such as West Africa.

It is worthy to note that against this background, farmers have been finding ways and means to adapt to the particularly drying conditions. These efforts have been often supported by research in order to provide a scientific evidence of the effectiveness of these adopted climate change adaptation options. This adoption is a reflection of the realities of climate change and variability on the ground and the ability of farmers to make informed choices from a range of available options. Prevalent technologies that have been used by farmers in the Sahel include stone bunds, zaï and half-moons.

\section{Are contour stone bunds successful CSA options in the Sahel? \\ Background information}

Two major factors characterizing agriculture in the Sahel are (i) erratic climatic conditions with frequent periods of water shortages and (ii) the presence of large areas of inherently low fertility and crust-prone soils [19]. What is responsible for water deficiency (i.e. more and/or longer periods of water stress) and low water use efficiency is not primarily water shortage but loss of water through runoff, soil evaporation and drainage below the root zone [8]. The loss through run-off is caused by the high intensity of the rainfall, the low organic matter content of the soils and the extent of soils with surface crusts and seals [20]. These have resulted in severe human-induced land degradation in the Sahel. Indeed, Oldeman et al. [21] indicated some years ago that in Africa, $40 \%$ of agricultural lands were affected by human-induced land degradation. Because of the degradation phenomenon, crops and animal production are at risk. To solve the problem, farmers have developed a range of measures, including run-off control, soil structure improvement and nutrient management [22].

Soil and water conservation extensionists have put an emphasis on the implementation of the stone bund technique to check run-off and to control erosion. Thus, laying stone bunds in the fields is now well known and is widely practiced by farmers in sub-Saharan West Africa [8]. Indeed, constructing stone bunds is the most widely practiced technique to combat run-off and erosion by farmers. As a result, various government and non-government programmes are promoting the large-scale introduction of the technique and providing technical and logistical backup for collecting and transporting stones. Contour stone bunds are erosion control structures built with quarry rock or stones in a series of two or three. They are constructed in lines along the natural contour of the land after 10-15 cm of the soil has been removed from the line where they are to be built. They should be built to a height of $20-30 \mathrm{~cm}$ from the ground and spaced $20-50 \mathrm{~m}$ apart depending on the inclination of the terrain.

On-farm research has shown that stone bunds are efficient in increasing the soil water status and in reducing soil erosion and downward particle transport. The technique is particularly efficient in reducing run-off and improving rainwater infiltration [8]; however, as shown in Tables 1 and 2 [23], the best results are achieved when contour stone bunds are used in combination with organic fertilizer application. Indeed, stone bunds with compost application showed the least water run-off during 3 years (Table 1). Plots with stone bunds maintained more moisture than plots with grass strips and plots without soil and water conservation (SWC) measures (Table 2).

Constructing stone bunds is the most widely practiced technique to combat run-off and erosion by farmers [25]. Indeed, plant nutrient use efficiency in cereal-based farming systems is often very low because of limited soil moisture conditions [26]. The low soil quality combined with the harsh Sahelian climate leads to a low efficiency of fertilizers [19]. The beneficial effect of SWC measures such as stone bunds on soil productivity was limited under continuous non-fertilized cereal cropping. However, interactions of SWC measures with organic or mineral source of nutrients optimize water and nutrient use efficiency [27], which can boost crop production and result in economic benefits for resource-poor farmers.

\section{Beneficial impacts for food production, adaptation and/or mitigation}

Under water-limiting conditions, the stone bunds are efficient measures in improving soil water content through run-off control, which can reach $59 \%$ in plots with barriers alone and even $84 \%$ in plots with barriers combined with organic matter [23]. The stone bunds form a barrier that slows down run-off and spreads it more evenly over the land. By slowing the flow of water over the land, it can seep into the soil and prevents the loss of rainwater. Rainwater that filters through the bunds infiltrates into the soil. When rainfall is erratic, the stone bunds contribute to conserving more moisture in the soil thereby helping to alleviate water stress during dry spells. The 
Table 1 Treatment effects on run-off during 2000, 2001 and 2002 rainy seasons at Saria, Burkina Faso

\begin{tabular}{|c|c|c|c|c|c|c|}
\hline & \multicolumn{3}{|c|}{ Annual run-off (\% of rainfall) } & \multicolumn{3}{|c|}{ Run-off reduction (\%) } \\
\hline & 2000 & 2001 & 2002 & 2000 & 2001 & 2002 \\
\hline $\mathrm{T}_{0}$ & $15.9(2.1)$ & $12.2(1.1)$ & $17.6(1.9)$ & 0 & 0 & 0 \\
\hline $\mathrm{T}_{\mathrm{SR}}$ & $7.1(2.0)$ & $3.5(1.3)$ & $5.0(0.9)$ & 55 & 71 & 71 \\
\hline $\mathrm{T}_{\text {SRU }}$ & $8.3(2.7)$ & $4.2(1.6)$ & $5.3(0.87)$ & 48 & 65 & 70 \\
\hline $\mathrm{T}_{\mathrm{SRC}}$ & $6.8(1.6)$ & $3.2(1.6)$ & $1.0(0.6)$ & 58 & 74 & 94 \\
\hline $\mathrm{T}_{\mathrm{GS}}$ & $8.3(1.1)$ & $5.9(1.0)$ & $8.2(1.3)$ & 48 & 51 & 53 \\
\hline $\mathrm{T}_{\mathrm{GSU}}$ & $11.4(0.9)$ & $9.5(1.1)$ & $7.6(2.2)$ & 29 & 22 & 57 \\
\hline $\mathrm{T}_{\mathrm{GSC}}$ & $7.1(1.6)$ & $4.5(1.8)$ & $2.8(1.2)$ & 56 & 63 & 84 \\
\hline $\mathrm{T}_{\mathrm{SRM}} / \mathrm{T}_{\mathrm{U}}$ & $7.5(2.2)$ & $6.6(0.9)$ & $9.0(1.0)$ & 53 & 46 & 49 \\
\hline $\mathrm{T}_{G S M} / T_{C}$ & $8.2(1.8)$ & $8.2(0.7)$ & $2.4(0.9)$ & 48 & 32 & 87 \\
\hline Number of rain events & 10 & 09 & 16 & 10 & 09 & 16 \\
\hline
\end{tabular}

Values in brackets: \pm standard deviation between run-off volumes measured in pits and recorded values of run-off. $T_{O}$ no SWC measures, no nutrient supply (control plot); $T_{S R}$ stone rows, no nutrient supply; $T_{S R C}$ stone rows + compost; $T_{S R M}$ stone rows + manure; $T_{S R U}$ stone rows + urea; $T_{G S}$ grass strips, no nutrient supply; $T_{G S C}$ grass strips + compost; $T_{G S M}$ grass strips + manure; $T_{G S U}$ grass strips + urea. Table adapted from Zougmoré et al. [24].

effect of stone bunds on soil water moisture depends on the space between the bunds. The larger the spacing, the less their effects [28]. In wet years however, the bunds may cause waterlogging in some parts of the field, which can adversely affect crop production. Contour stone bunds protect the land against sheet erosion caused by run-off. Some studies reported that the application of compost led to the reduction of total soil loss by $79 \%$ in plots with stone bunds as compared to the losses in plots without barriers [24]. By slowing down the run-off speed, the bunds also induce sedimentation of fine waterborne particles of soil and manure, resulting in a build-up of a layer of sediments rich in nutrients. The seeds of grasses and shrubs are also trapped by the bunds, favouring the establishment of natural vegetation along the structure. This further stabilizes the soil and the bunds and contributes to conserving the biodiversity of plants and small wild animals (monitor lizards, birds,

Table 2 Treatment effects on volumetric soil water content in the root zone (\%) at Saria, Burkina Faso

\begin{tabular}{|c|c|c|c|}
\hline & 06 August 2000 & 27 August 2001 & 15 July 2002 \\
\hline $\mathrm{T}_{\text {SRU }}$ & $18.9(1.7)^{\mathrm{a}}$ & $14.4(0.7)^{\mathrm{a}}$ & $12.4(0.4)^{\mathrm{a}}$ \\
\hline $\mathrm{T}_{\mathrm{SR}}$ & $16.3(1.6)^{b}$ & $12.8(1.0)^{b}$ & $11.4(1.1)^{b}$ \\
\hline $\mathrm{T}_{\mathrm{GSC}}$ & $16.5(1.6)^{b}$ & $13.4(1.9)^{b}$ & $09.3(0.6)^{e}$ \\
\hline $\mathrm{T}_{\mathrm{GSU}}$ & $16.1(1.3)^{b}$ & $10.5(0.7)^{d}$ & $10.0(0.4)^{c d}$ \\
\hline $\mathrm{T}_{\mathrm{SRM}} / \mathrm{T}_{\mathrm{U}}$ & $15.8(1.8)^{b}$ & $10.4(0.6)^{d}$ & $10.3(0.3)^{c}$ \\
\hline $\mathrm{T}_{\mathrm{SRC}}$ & $15.2(1.3)^{\mathrm{bc}}$ & $10.9(0.5)^{d}$ & $08.6(0.5)^{f}$ \\
\hline $\mathrm{T}_{\mathrm{GS}}$ & $14.4(1.0)^{c}$ & $12.1(0.6)^{c}$ & $10.3(0.6)^{c}$ \\
\hline $\mathrm{T}_{\mathrm{GSM}} / \mathrm{T}_{\mathrm{C}}$ & $14.2(1.4)^{c}$ & $11.6(1.0)^{c}$ & $09.8(0.7)^{d}$ \\
\hline $\mathrm{T}_{0}$ & $14.0(1.1)^{c}$ & $10.1(1.3)^{d}$ & $10.1(0.6)^{c d}$ \\
\hline Probability & $<0.001$ & $<0.001$ & $<0.001$ \\
\hline
\end{tabular}

$a, b, c, d, e, f$ express statistical differences. Treatments with the same letter are not statistically different at $P=0.05$. Values in brackets: \pm standard deviation. Treatment keys in Table 1. Table adapted from Zougmoré et al. [24]. snakes and other reptiles). From the perspective of climate change adaptation, contour stone bunds are useful for a number of reasons. In years with high rainfall, they protect the land from rapid flow and associated erosion in the event of a heavy rain, a phenomenon that tends to increase with climate change. In years with a decline in rainfall, they contribute to more effective rainwater harvesting. They improve water retention and infiltration into the soil, increasing the amount of water available to plants and guaranteeing the harvest. Such an increase in available water in the soil profile will help to mitigate the predicted decrease in the length of growing period (LGP) in the Sahel due to global warming [17]. In addition, IPCC [18] projects that heavy rainfall events in the Sahel are likely to increase in frequency and intensity. And with the development of an important tree cover along the stone bunds, they also lower soil temperature and provide protection against wind erosion. In addition to increasing the adaptive capacity, the better management of these lands may lead to increased productivity.

During dry years, crops in plots with stone bunds could yield two to three times more than crops in control plots [25]. The increase in sorghum yields varies between 33\% and 55\% in Burkina Faso's Central Plateau area while grain yields increase by more than $40 \%$ for millet up to 15 years after the bunds were established in Niger [29]. A similar picture also emerged in Niger where farm families with SWC produced an estimated grain surplus of $70 \%$ in years of good rainfall [30]. Zougmoré et al. [27] reported that the yield increase did not cover annual costs of single SWC measures while application of single compost or urea was cost effective. Combining stone bunds with application of compost increased sorghum grain yield by about $142 \%$ and induced positive interaction effects (mean added effects of $185 \mathrm{~kg} \mathrm{ha}^{-1}$ for stone bunds combined with compost), which resulted in financial gains of 
145,000 to 180,000 FCFA ha ${ }^{-1}$ year $^{-1}$ under adequate rainfall conditions (Table 3 ). These results indicate that despite the harsh Sahelian environment, opportunities do exist for making a more efficient use of the limited local sources in a way to develop CSA options such as contour stone bunds.

Landolt [29] identified a range of both poverty and hunger reduction benefits (increased yields, introduction of cash crops, greater food security and income) and environmental benefits (raised water tables, increased vegetation cover, increased stock of trees, reduced pressure on nearby savannahs, increased species diversity) when contour stone bunds were constructed and organic fertilizer was used. Higher crop production improves household food security in proportion to the area of a farm improved with bunds. Under the Niger project for integrated protection of agro-sylvo-pastoral resources, an average of $16 \%$ of the area of a farm was improved with stone bunds, resulting in an increase of between $8 \%$ and $33 \%$ in annual output with no other additional measures [29]. In some areas, a reduction in temporary migration to pursue off-farm income-generating activities was also observed. The above results show that applying the stone bund technique can strengthen the adaptive capacity of farmers while empowering them to invest in soil fertilization for increased productivity and food security.

Thanks to the stone bunds, the increased vegetation cover and diversity on the rehabilitated areas can also increase the supply of fuel wood. As a result, more organic matter is being applied to fields instead of being used as fuel, further increasing soil fertility and crop yields. This could be an opportunity for soil carbon sequestration if the crop biomass and other organic resources are maintained in the soil while preventing erosion. Also, the vegetation that grows also contributes towards the mitigation by absorbing carbon dioxide from the atmosphere. As groundwater levels rise, farmers started growing vegetables on small plots near wells, thereby increasing both their income and the diversity of their diets. Health benefits from this are likely to be significant, although have yet to be measured. In that respect, durable and effective soil erosion control structures such as stone bunds will assume even greater importance and constitute an important adaptation measure with possible mitigation co-benefits.

\section{Zaï and half-moons: two indigenous land rehabilitation practices to adapt to the changing climate and land use in the Sahel \\ Background information}

In the West African Sahel, the combined effects of climatic conditions, inherent poor soil quality and human activities have resulted in soil degradation. The latter is due to crusting, sealing, erosion by water and wind. Cultivated lands are particularly characterized by a gradual loss of structure, hardpan formation, reduced permeability, compaction, inadequate aeration and limited plant root development. On these soils, increasing erosion has ultimately resulted into the development of totally bare, sealed and crusted soils locally called zipellé in Burkina Faso, or harde soils in Chad [8]. No one single measure is sufficient to adapt to climate change and variability. Rather, a mix of measures is needed to target the various farm variables-water, soil, micro-climate, seeds and crops as well as labour and capital.

This example shows how traditional integrated soil and water management practices called $z a \ddot{i}$ and half-moons can combat land degradation and improve productivity of these previously abandoned bared soils. The zaï method (also called tassa in Niger or towalen in Mali) is a soil rehabilitation system that concentrates run-off water and organic matter in small pits. With an average of 20-40 cm in diameter and 10-15 cm deep, the holes are dug manually during the dry season. A handful $(\approx 0.3 \mathrm{~kg})$ of animal manure or compost is supplied per pit, i.e. $9.5 \mathrm{t} \mathrm{ha}^{-1}$. Like $z a \ddot{i}$, the half-moon technique (originating from Niger) is another method for the rehabilitation of sealed and crusted bare soils consisting of a basin of $2 \mathrm{~m}$ in diameter. The digging is done with a hoe or a pick so as to break the crusted layer on the soil surface and to collect the run-off water. The cultivated area is $6.3 \mathrm{~m}^{2}$ for each half-moon. A barrowful (35 kg) of animal manure or compost is supplied in each half-moon, i.e. $14.6 \mathrm{t} \mathrm{ha}^{-1}$. Stone bunds are usually laid along contours in order to slow down run-off and allow better water retention and infiltration in the zaï and half-moon basins.

Table 3 Economic benefits of combining stone rows or grass strips with compost-N or urea-N at Saria

\begin{tabular}{|c|c|c|c|c|c|c|c|c|}
\hline & \multicolumn{4}{|l|}{2001} & \multicolumn{4}{|l|}{2002} \\
\hline & $\mathrm{T}_{\mathrm{SRU}}$ & $\mathrm{T}_{\mathrm{GSU}}$ & $\mathrm{T}_{\mathrm{SRC}}$ & $\mathrm{T}_{\mathrm{GSC}}$ & $T_{\text {SRU }}$ & $T_{\text {GSU }}$ & $\mathrm{T}_{\mathrm{SRC}}$ & $\mathrm{T}_{\mathrm{GSC}}$ \\
\hline Minimum yield for $\mathrm{N}$ inputs $\left(\mathrm{kg} \mathrm{ha}^{-1}\right)$ & 195 & 195 & 271 & 271 & 195 & 195 & 271 & 271 \\
\hline Minimum yield for SWC measures $\left(\mathrm{kg} \mathrm{ha}^{-1}\right)$ & 345 & 187 & 345 & 187 & 345 & 187 & 345 & 187 \\
\hline Minimum yield for SWC $+\mathrm{N}$ input $\left(\mathrm{kg} \mathrm{ha}^{-1}\right)$ & 540 & 382 & 615 & 457 & 540 & 382 & 615 & 457 \\
\hline Excess yield $\left(\mathrm{kg} \mathrm{ha}^{-1}\right)$ & 158 & 54 & 821 & 782 & -193 & -135 & 987 & 915 \\
\hline Economic benefit (FCFA ha ${ }^{-1}$ ) & 22,120 & 7,560 & 114,940 & 109,480 & $-27,020$ & $-18,900$ & 138,180 & 128,100 \\
\hline
\end{tabular}

$T_{S R C}$ stone rows + compost-N $T_{G S C}$ grass strips + compost- $\mathrm{N}, T_{S R U}$ stone rows + urea-N, $T_{G S U}$ grass strips + urea-N. Table adapted from Zougmoré et al. [24]. 


\section{Beneficial impacts for food production, adaptation and/or mitigation}

The two soil rehabilitation practices are efficient in improving soil productivity mainly through biophysical and biological processes. Indeed, by breaking the soil crust, pit digging facilitates more water infiltration; also, runoff water is harvested due to the earthen bund formed downslope of the pits. The applied organic matter attracts termites which develop nesting and foraging activities. This results in improved soil structure as they open up large and numerous macropores throughout the entire soil profile. The soil structure enhancement following soil fauna activity leads to increased water infiltration and drainage, lower run-off and reduced soil resistance to root penetration. Moreover, the application of organic inputs not only enhances soil nutrient availability but also improves crop nutrient uptake from soil reserves. The improvement of water status in the soil and the increased decomposition and nutrient release result into a beneficial impact of the zaï and half-moon systems on crop performance under semiarid conditions. Several studies $[20,22]$ in the Sahel region reported that applying compost with mineral fertilizers allowed substantial gain in sorghum grain yields from the zaï pits without any organic or mineral supply (Table 4).

It is a practical solution to reclaim these degraded lands but also to rehabilitate the agroforestry cover in the Soudano-Sahelian semiarid area. Indeed, the plant seeds included in the manure allow the regeneration of shrubs and trees in the zaï pits. In line with their objective to restore vegetation in their lands and to expect beneficial by-products from trees, farmers generally proceed to a selection of regenerated young trees; then they are assisted until they become mature plants. Several studies reported the re-establishment on formerly bare soil of over 20 herbaceous species and 15 woody species following two consecutive years of zaï in the central part of Burkina Faso $[10,31]$. The $z a \ddot{i}$ method at present is still labourintensive, about 60 working days for 1 ha. Scientists from the National Institute for Environment and Agricultural Research in Burkina Faso recommended a so-called 'mechanical zai that consists of making appropriate holes mechanically with animal-drawn tools (Dent IR12 for sandy soils or Dent RS8 for other types of soils). This reduces by more than $90 \%$ the amount of time required for making the pits. Indeed, it takes only 11 to $22 \mathrm{~h} \mathrm{ha}^{-1}$ to construct these pits with oxen that are well fed with crop residues [32]. This also resulted into an economic benefit of $165,000 \mathrm{CFA} \mathrm{ha}^{-1}$ compared to only $17,000 \mathrm{CFA} \mathrm{ha}^{-1}$ with the manually dug zaï (Table 5).

However, it is worth mentioning that the widespread use of the mechanical zaï technique is still constrained by the non-affordable cost of the animal-drawn equipment and tools [32]. Thus, a long-term trade-off may consist in developing local capacities within farmer communities in order to empowering them to produce and sell locally the basic agricultural equipment (e.g. plough, cart, pick, shovel). This should be accompanied by widespread promotion of compost production in order to contribute to solving the limited availability of animal manure.

The above results demonstrate that zaï and half-moon practices can be considered as CSA options as they contribute effectively to rehabilitate previously abandoned and degraded bare lands. Therefore, they improve the

Table 4 Grain and biomass production on deep, brown Eutropept soil, at Taonsogo, Burkina Faso

\begin{tabular}{|c|c|c|c|c|c|c|}
\hline \multirow[t]{2}{*}{ Treatment } & \multicolumn{3}{|l|}{1992} & \multicolumn{3}{|l|}{1993} \\
\hline & $\mathrm{Kg} \mathrm{ha}^{-1}$ & \pm S.D. & Test $^{1}$ & $\mathrm{Kg} \mathrm{ha}^{-1}$ & \pm S.D. & Test $^{1}$ \\
\hline \multicolumn{7}{|l|}{ Grain production } \\
\hline Control & 150 & \pm 154 & a & 3 & \pm 0.6 & a \\
\hline Pit & 200 & \pm 63 & a & 13 & \pm 4.2 & a \\
\hline Pit + neem leaves & 395 & \pm 151 & $a b$ & 24 & \pm 7.3 & a \\
\hline Pit + compost $^{2}$ & 654 & \pm 145 & $a b c$ & 123 & \pm 82.5 & a \\
\hline Pit + mineral fertilizer & 1,383 & \pm 236 & bc & 667 & \pm 256.3 & $b$ \\
\hline Pit + compost + mineral fertilizer & 1,704 & \pm 305 & bc & 924 & \pm 346.8 & $b$ \\
\hline \multicolumn{7}{|l|}{ Biomass production } \\
\hline Control & 946 & \pm 529 & a & 167 & \pm 75 & a \\
\hline Pit & 1,329 & \pm 549 & a & 292 & \pm 49 & a \\
\hline Pit + neem leaves & 1,990 & \pm 207 & $a b$ & 875 & \pm 172 & $a b$ \\
\hline Pit + compost $^{2}$ & 2,843 & \pm 945 & $a b c$ & 1,417 & \pm 511 & $b c$ \\
\hline Pit + mineral fertilizer & 4,839 & $\pm 1,105$ & $b c$ & 2,375 & \pm 706 & bcd \\
\hline Pit + compost + mineral fertilizer & 5,333 & $\pm 1,490$ & $b c$ & 3,250 & \pm 857 & $\mathrm{~cd}$ \\
\hline
\end{tabular}

${ }^{1}$ Tukey-Kramer test $(P<0.05)$. a, b, c, d express statistical differences. Treatments with the same letter are not statistically different at $P=0.05$.

${ }^{2}$ Compost: $3 \mathrm{Mg} \mathrm{ha}^{-1}$ of a mixture of dry manure, straw and various crop residues composted during three dry months. Table adapted from Roose et al. [20]. 
Table 5 Economic evaluation of the treatments at Pougyango (CFA/ha)

\begin{tabular}{llllll}
\hline & Control & Soil scarifying & Manual zaï & Mechanized zaï with excavation & Mechanized zaï \\
\hline Soil tillage cost & 0 & 3,000 & 55,000 & 26,900 & 15,000 \\
Total cost & 58,333 & 69,003 & 166,698 & 93,659 & 76,790 \\
Income grains & 29,820 & 49,560 & 146,160 & 201,740 & 191,380 \\
Income straw & 12,668 & 14,220 & 37,808 & 56,970 & 52,748 \\
Total income & 42,488 & 63,780 & 183,968 & 258,710 & 244,128 \\
Benefit (income-cost) & -15846 & $-5,223$ & 17,270 & 165,051 & 167,337 \\
Additional costs & - & 0 & 52,000 & 23,900 & 12,000 \\
Total benefits & - & 0 & 120,188 & 194,930 & 180,348 \\
Ratio cost/benefit & - & - & 2,31 & 8.16 & 15.03
\end{tabular}

1 euro $=655.95$ CFA (Table adapted from Barro et al. [32]).

resilience of smallholder farmers; in addition, these practices substantially increase crop productivity and allow farmers to adapt to climate variability. Also, according to Bayala et al. [10], zaï and half-moon techniques also favour local species regeneration through their seeds contained in the manure applied. A sound application of these techniques can potentially contribute to GHG reduction through the subsequent impact of the regenerated trees and their effect on soil carbon and crop production. However, these aspects still need further investigation, especially in relation to how trees are managed by farmers.

\section{Conclusion}

In this paper, we reviewed data and information on three integrated soil water and nutrient management practices from the semiarid West African region to analyse their contribution to the three pillars of CSA. The goal is to simultaneously achieve increased agricultural productivity and incomes (food security), improved resilience to climate change (adaptation) and reduction of greenhouse gas emissions (mitigation), where possible. We found that stone bunds, zaï and half-moon techniques combined with the application of organic and/or mineral fertilizers are sustainable land management practices that have increased agricultural productivity, vegetative cover and carbon sequestration. They also reduce water erosion. Thus, in the context of the West African Sahel, these techniques can be qualified as climate-smart since in various ways, they contribute to the CSA criteria. However, constraints that may limit their adoption and sustainability are mainly the specific requirement of rocks in order to construct the contour stone bunds and the corollary need for considerable cost and labour to collect and transport the rocks from their original locations to the fields. Vegetation barriers can also be considered as an alternative. Planting locally adapted grass strips (e.g. of Andropogon gayanus) or live hedges (e.g. of Guiera Senegalensis, Piliostigma reticulatum) may be sustainable solutions if farmers ensure their maintenance (pruning, protection). Also, in view of the limited availability of organic matter to be applied with the zaï, halfmoon and stone bund techniques, compost production should be encouraged in order to valorize the scarce organic resources in the region. Therefore, developing local capacities and empowering rural communities to produce good quality compost and to manufacture basic agricultural equipment could contribute to reducing the labour demand while enabling the widespread implementation of the technique. These successful examples show the many ways CSA can take shape and should serve as inspiration for future policies and investments. It seems therefore important to recognize the opportunities and limitations of specific climate-smart techniques as they can be applied in specific locations when designing local, national and sub-regional agricultural and food security investment plans. There is a growing support for CSA promotion through the formation of global, continental and regional alliances around the concept. Hence, categorizing these technologies according to their climate-smartness will contribute to giving practical evidence of CSA concept to farmers. This may facilitate the widespread adoption and out scaling of these CSA technologies and practices amongst farmers in West Africa.

Competing interests

The authors declare that they have no competing interests.

Authors' contributions

RZ developed the outline and drafted the manuscript. AJ and AT contributed to the evolving outline and writing of the manuscript. All authors read and approved the final manuscript.

\section{Acknowledgements}

The authors acknowledge support provided by the CGIAR Research Program on Climate Change, Agriculture and Food Security (CCAFS) with funding from the CGIAR Fund and the European Union (EU) and with technical support from the International Fund for Agricultural Development (IFAD). They also thank CORAF/WECARD and ROPPA for their collaboration and contribution to this paper. 


\section{Author details}

${ }^{1}$ CGIAR Research Program on Climate Change, Agriculture and Food Security (CCAFS), ICRISAT Bamako, BP 320 Bamako, Mali. ${ }^{2}$ West and Central African Council for Agricultural Research and Development (CORAF/WECARD), BP 48 Dakar, RP, Senegal. ${ }^{3}$ Réseau des Organisations Paysannes et de Producteurs Agricoles de l'Afrique de l'Ouest (ROPPA), 09 BP 884 Ouagadougou 09, Burkina Faso.

Received: 17 July 2014 Accepted: 23 September 2014 Published: 3 November 2014

\section{References}

1. Elbehri A, Kaminski J, Koroma S, lafrate M, Benali M: West Africa food systems: an overview of trends and indicators of demand, supply, and competitiveness of staple food value chains. In Rebuilding West Africa's Food Potential: Policies and Private Initiatives to Promote Smallholder-Inclusive Staple Food Value Chains. Edited by FAO. Rome: Inter-Departmental Working Group; 2013:1-42

2. Winterbottom R, Reij C, Garrity D, Glover J, Hellums D, Mcgahuey M, Scher S: Improving Land and Water Management. Working Paper, Installment 4 of Creating a Sustainable Food Future. Washington, DC: World Resources Institute; 2013 [http://www.worldresourcesreport.org]

3. The Montpellier Panel: Sustainable Intensification: A New Paradigm for African Agriculture. London: Agriculture for Impact, Imperial College; 2013:1-36.

4. Lobell DB, Schlenker WS, Costa-Roberts J: Climate trends and global crop production since 1980. Science 2011, 333:616-620.

doi:10.1126/science.1204531.

5. Jarvis A, Lau C, Cook S, Wollenberg E, Hansen J, Bonilla O, Challinor A: An integrated adaptation and mitigation framework for developing agricultural research: synergies and trade-offs. Exp Agric 2011, 47:185-203.

6. Neufeldt H, Jahn M, Campbell BM, Beddington JR, DeClerck F, De Pinto A, Gulledge J, Hellin J, Herrero M, Jarvis A, LeZaks D, Meinke H, Rosenstock T, Scholes M, Scholes R, Vermeulen S, Wollenberg E, Zougmoré R: Beyond climate-smart agriculture: toward safe operating spaces for global food systems. Agric Food Secur 2013, 2:12.

7. Jalloh A, Nelson GC, Thomas TS, Zougmoré R, Roy-Macauley H: West African agriculture and climate change: a comprehensive analysis. Washington DC: IFPRI Books and research monographs; 2013. http://dx.doi.org/10.2499/ 9780896292048. ISBN 978-0-89629-204-8.

8. Zougmoré R, Ouattara K, Mando A, Ouattara B: Rôle des nutriments dans le succès des techniques de conservation des eaux et des sols (cordons pierreux, bandes enherbées, zaï et demi-lunes) au Burkina Faso. Sécheresse 2004, 15:41-48.

9. Zougmoré R: Integrated water and nutrient management for sorghum production in semi-arid Burkina Faso. Tropical Resources Management Papers, Volume 45. The Netherlands: Wageningen University; 2003.

10. Bayala J, Sileshi GW, Kalinganire A, Tchoundjeu Z, Sinclair F, Garrity D: Cereal yield response to conservation agriculture practices in drylands of West Africa: a quantitative synthesis. J Arid Environment 2012, 78:13-25.

11. Nicholson S, Selato J: The influence of La Niña on African rainfall. Int J Climatol 2000, 20:1761-1776.

12. Cook K, Vizy E: Coupled model simulations of the West African monsoon system: twentieth and twenty first century simulations. J Clim 2008, 19:3681-3703.

13. Dai A: Precipitation characteristics in eighteen coupled climate models. J Clim 2006, 19:4605-4630

14. Washington R, Hawcroft M: Climate Change in West African Agriculture: Recent Trends, Current Projections, Crop-Climate Suitability, and Prospects for Improved Climate Model Information. Denmark, Copenhagen: CCAFS; 2012 [www.ccafs.cgiar.org]

15. Giannini A: Mechanisms of climate change in the semiarid African Sahel: the local view. J Clim 2010, 23:743-756.

16. Haarsma RJ, Selten FM, Weber SL, Kliphuis M: Sahel rainfall variability and response to greenhouse warming. Geophysical Res Lett 2005, 32:L17702.

17. Ericksen $P$, Thornton $P$, Notenbaert $A$, Cramer L, Jones $P$, Herrero M: Mapping hotspots of climate change and food insecurity in the global tropics, CCAFS Report 5. Denmark, Copenhagen: CCAFS; 2011. Available online at: [www.ccafs.cgiar.org]

18. IPCC: Climate Change: The Physical Science Basis. In Contribution of Working Group I to the Fifth Assessment Report of the Intergovernmental Panel on Climate Change. Edited by Stocker TF, Qin D, Plattner GK, Tignor M, Allen
SK, Boschung J, Nauels A, Xia Y, Bex V, Midgley PM. Cambridge, United Kingdom and New York, NY, USA: Cambridge University Press; 2013:1-1535.

19. Breman H, Groot JJR, van Keulen H: Resource limitations in Sahelian agriculture. Glob Environ Changes 2001, 11:59-68.

20. Roose E, Kaboré V, Guenat C: Zaï practice: A West African traditional rehabilitation system for semiarid degraded lands: a case study in Burkina Faso. Arid Soil Res Rehabil 1999, 13:343-355.

21. Oldeman LR, Hakkeling RTA, Sombroek WG: World map of the status of human-induced soil degradation. An explanatory note. 2nd edition. ISRIC, UNEP: Wageningen, Nairobi; 1991.

22. Reij C, Tappan G, Smale M: Re-greening the Sahel: farmer-led innovation in Burkina Faso and Niger. In Agro-Environmental Transformation in the Sahel: Another Kind of "Green Revolution". Washington DC: IFPRI Discussion Paper; 2009:1-52. 914.

23. Zougmoré R, Mando A, Ringersma J, Stroosnijder L: Effect of combined water and nutrient management on runoff and sorghum performance in semiarid Burkina Faso. Soil Use Manag 2003, 19:257-264.

24. Zougmoré R, Mando A, Stroosnijder L: Soil nutrient and sediment loss as affected by erosion barriers and nutrient source in semi-arid Burkina Faso. Arid Land Res Manage 2009, 23:85-101.

25. Kaboré PD, Reij C: The emergence and spreading of an improved traditional soil and water conservation practice in Burkina Faso. IFPRI discussion paper 114 Washington DC: Environment and production technology division; 2004.

26. Buerkert A, Piepho HP, Bationo A: Multi-site time-trend analysis of soil fertility management effects on crop production in sub-Saharan West Africa. Exp Agric 2002, 38:163-183.

27. Zougmoré R, Mando A, Stroosnijder L: Economic benefits of combining soil and water conservation measures with nutrient management in semiarid Burkina Faso. Nutr Cycl Agroecosyst 2004, 70:261-269.

28. Zougmoré R, Guillobez S, Kambou NF, Son G: Runoff and sorghum performance as affected by the spacing of stone lines in the semiarid Sahelian zone. Soil Tillage Res 2000, 56:175-183.

29. Landolt M: Stone lines against desertification. Rural 21 International Platform; 2011:36-37. 1

30. Hassan A: Improved traditional planting pits in the Tahoua Dep. (Niger): an example of rapid adoption by farmers. In Sustaining The Soil Indigenous Soil and Water Conservation in Africa. Edited by Reij C, Scoones I Earthscan TC; 1996:56-61

31. Mando A, Zougmoré $\mathrm{R}$, Zombré NP. Hien V: Réhabilitation des sols dégradés dans les zones semi-arides de l'Afrique subsaharienne. In La jachère en Afrique Tropicale; de la jachère naturelle à la jachère améliorée. Le point des connaissances. Edited by Floret C, Pontanier R. Paris: John Libbey Eurotext; 2001:311-339. Volume II.

32. Barro A, Zougmoré $\mathrm{R}$, Taonda SJB: Mécanisation de la technique du zaï manuel en zone semi-aride. Cahiers Agric 2005, 14:549-559.

doi:10.1186/2048-7010-3-16

Cite this article as: Zougmoré et al.: Climate-smart soil water and nutrient management options in semiarid West Africa: a review of evidence and analysis of stone bunds and zaï techniques. Agriculture \& Food Security 2014 3:16.

\section{Submit your next manuscript to BioMed Central and take full advantage of:}

- Convenient online submission

- Thorough peer review

- No space constraints or color figure charges

- Immediate publication on acceptance

- Inclusion in PubMed, CAS, Scopus and Google Scholar

- Research which is freely available for redistribution 